\title{
RAPD and ISSR molecular markers in Olea europaea L.: Genetic variability and molecular cultivar identification
}

\author{
Paula Martins-Lopes ${ }^{1}$, José Lima-Brito ${ }^{1}$, Sónia Gomes ${ }^{1}$, Julieta Meirinhos ${ }^{1}$, Luís Santos ${ }^{2}$ \\ and Henrique Guedes-Pinto ${ }^{1, *}$ \\ ${ }^{I}$ Department of Genetics and Biotechnology, Centre of Genetics and Biotechnology, University of Trás-os- \\ Montes and Alto Douro, P.O. Box 1013, 5000-911 Vila Real, Portugal; ${ }^{2}$ Department of Oliviculture, National \\ Plant Breeding Station, INIA, P.O. Box 6, 7350-951 Elvas, Portugal; *Author for correspondence (e-mail: \\ hgp@utad.pt; phone: +351-259350595; fax: +351-259350572)
}

Received 12 April 2004; accepted in revised form 14 August 2005

Key words: Genetic variability, ISSR, Molecular cultivar identification, Olea europaea L., RAPD

\begin{abstract}
Thirty Portuguese and eight foreign olive (Olea europaea L.) cultivars were screened using Random Amplified Polymorphic DNA (RAPD) and Inter-Simple Sequence Repeat (ISSR) markers. Twenty RAPD primers amplified 301 reproducible bands of which 262 were polymorphic; and 17 ISSR primers amplified 204 bands of which 180 were polymorphic. The percentage of polymorphic bands detected by ISSR and RAPD was similar ( 88 and $87 \%$, respectively). The genetic variability observed was similar in the Portuguese and foreign olive cultivars. Seven ISSR and 12 RAPD primers were able to distinguish individually all 38 olive cultivars. Twenty specific molecular markers are now available to be converted into Sequence Characterised Amplified Region (SCAR) markers. Relationships among Portuguese and foreign cultivars is discussed.
\end{abstract}

\section{Introduction}

The olive tree, Olea europaea L., has been part of the Mediterranean civilisation since before recorded history. Its domestication goes back 6000 years to the East coast of the Mediterranean Sea (Zohary and Spiegel 1975). In the Mediterranean countries olive orchards cover about $7,000,000$ ha (Khadari et al. 2003), and olive oil is an important product due to its nutritional and health advantages in comparison to other vegetable oils (Rallo et al. 2000).

Olive tree germplasm was traditionally evaluated by morphological and phenological parameters. Polymerase Chain Reaction (PCR) - based
DNA markers are powerful tools for genetic analysis because of their simplicity and ease handling (Kojima et al. 1998) providing an opportunity for direct comparison and identification of olive tree material independently from environment and/or developmental stages. Random amplified polymorphism DNA (RAPD) markers (Williams et al. 1990) are a promising marker system widely used in plant research such as phylogenetic studies, genome mapping, population genetic studies, as well as in cultivar identification and germplasm management (Schnell et al. 1995; Ford et al. 1997; Loureiro et al. 1998; Qian et al. 2001; Bandelj et al. 2002). This technique has several advantages such as: simplicity of use, low 
cost and the use of a small amount of plant material (Fritsch and Rieseberg 1996). However, RAPD technology has several limitations including dominance, uncertain locus homology, sensitivity to the reaction conditions, and reliability from lab to lab.

RAPDs have been used in the differentiation of olive cultivars (Cresti et al. 1996; Khadari et al. 2003), to study inter- or intra-cultivar genetic diversity (Wiesman et al. 1998; Mekuria et al. 1999, 2002, Roselli et al. 2002, Belaj et al. 2002, 2003b, c; Gemas et al. 2004), to establish genetic relationships between cultivars (Belaj et al. 2002, 2003b; Besnard et al. 2001a; Khadari et al. 2003), and to study genetic differentiation in the olive complex (Besnard et al. 2001b).

In order to solve some of the problems associated with RAPD, new techniques, such as ISSR were developed (Zietkiewicz et al. 1994). ISSR technique is based on the amplification of regions (100-3,000 bp) between inversely oriented closely spaced microsatellites. ISSRs are PCR products obtained with primers based on dinucleotide, trinucleotide, tetranucleotide and pentanucleotide repeats (Zietkiewicz et al. 1994), and have been used for olive cultivar identification (Hess et al. 2000; Pasqualone et al. 2001; Gemas et al. 2004; Terzopoulos et al. 2005).

The major advantage of ISSR markers is the fact that they do not require the time-consuming and expensive step of genomic or other library construction (Rakoczy et al. 2004), do not need prior knowledge of DNA sequence for primer design, and have similar advantages to RAPDs (Kantety et al. 1995; Yang et al. 1996; Fang and Roese 1997). ISSR amplification has been shown to be much more informative than RAPDs for genetic diversity evaluation in wheat (Triticum aestivum), in fruit plants and common bean (Phaseolus vulgare) (Nagaoka and Ogihara 1997; Korbin et al. 2002; Galvan et al. 2003). Previous studies have concluded that ISSR markers will be efficient to assess phylogenetic relationships in the Olea europaea complex (Hess et al. 2000; Gemas et al. 2004) and to identify drupes from different olive cultivars (Pasqualone et al. 2001).

The main goal of this work was to construct a molecular data-base using RAPD and ISSR markers for Olea europaea, to obtain specific molecular markers for individual identification of all the thirty Portuguese 'standard' olive tree cultivars and eight foreign cultivars from eight different Mediterranean countries, to study their genetic variability, and to search for synonymy and homonymy.

\section{Materials and methods}

\section{Leaf materials}

Leaf samples from 38 olive cultivars were gathered in the field collection of Oliviculture Department of the Portuguese National Breeding Station, Elvas, and frozen in liquid nitrogen and stored at $-80^{\circ} \mathrm{C}$. Thirty cultivars are standard Portuguese cultivars and the remaining eight from the following Mediterranean countries: France, Greece, Italy, Israel, Morocco, Spain, Tunisia and Turkey (Table 1).

\section{DNA extraction}

Genomic DNA was extracted from fresh young olive leaves by a modified CTAB method following the procedure described by Doyle and Doyle (1987). Five grams of leaves were grounded in liquid nitrogen and incubated at $65^{\circ} \mathrm{C}$, for $1 \mathrm{~h}$ in $15 \mathrm{~mL}$ of extraction buffer $[100 \mathrm{mM}$ Tris- $\mathrm{HCl} \mathrm{pH}$ 8.0, 1.4 M NaCl, 20 mM EDTA, 2\% (w/v) CTAB, $2 \%(\mathrm{w} / \mathrm{v})$ PVP and $1 \%(\mathrm{v} / \mathrm{v}) \beta$-mercaptoethanol]. An extraction with an equal volume of chloroform-isoamyl alcohol $(24: 1-\mathrm{v} / \mathrm{v})$ and a centrifugation at $10,000 \mathrm{rpm}$ for $50 \mathrm{~min}$ was repeated. RNA was removed from the aqueous solution by RNase $(100 \mu \mathrm{g} / \mathrm{mL})$ treatment (Sigma, St. Louis, MO, USA) at $37^{\circ} \mathrm{C}$ for $1 \mathrm{~h}$. After the isopropanol $(0.6 \mathrm{~V})$ precipitations, DNA was recovered and washed with $5 \mathrm{~mL}$ of buffer $(76 \%$ ethanol and $10 \mathrm{mM}$ ammonium acetate), dried and resuspended in $0.2 \mathrm{ml}$ of TE buffer $(10 \mathrm{mM}$ Tris- $\mathrm{HCl}$ pH 8.0; 1 mM EDTA pH 8.0). DNA concentration was determined by spectrophotometer and was checked for integrity on a $0.7 \%$ agarose gel.

\section{RAPD amplification}

The effects of Taq polymerase concentrations, template DNA concentrations, and different periods of time and temperatures during the annealing 
Table 1. List of olive cultivars studied, their geographical region of production, end use, oil content and country of origin.

\begin{tabular}{|c|c|c|c|c|c|}
\hline Code & Cultivar & Geographic region of production & End use & Oil content $\mathrm{t}^{\mathrm{a}}$ & Country \\
\hline PT1 & Azeiteira & Alentejo & Table & Low & Portugal \\
\hline PT2 & Blanqueta & Norte Alentejo & Oil & Medium & \\
\hline PT3 & Borrenta & Trás-os-Montes & Oil & Low & \\
\hline PT4 & Carrasquenha & Elvas and Campo Maior (Alentejo) & Oil & High & \\
\hline PT5 & Cobrançosa & Trás-os-Montes, Alentejo, Ribatejo and Beiras & Oil & Medium & \\
\hline PT6 & Conserva de Elvas & Elvas (Alentejo) & Table & Medium & \\
\hline PT7 & Cordovil de Castelo Branco & Beira Interior & Both use & Medium & \\
\hline PT8 & Cordovil de Elvas & Elvas (Alentejo) & Oil & Medium & \\
\hline PT9 & Cordovil de Serpa & Serpa and Moura (Alentejo) & Oil & Medium & \\
\hline PT10 & Cordovil de Trás-os-Montes & Trás-os-Montes & Oil & Medium & \\
\hline PT11 & Cornicabra & Beira Alta & Oil & High & \\
\hline PT12 & Galega & Alentejo, Ribatejo and Beiras & Oil & Medium & \\
\hline PT13 & Galego de Évora & Évora (Alentejo) & Oil & Medium & \\
\hline PT14 & Galego Grado de Serpa & Serpa and Moura (Alentejo) & Oil & Medium & \\
\hline PT15 & Golosinha & Elvas (Alentejo) & Oil & High & \\
\hline PT16 & Leucocarpa & Santarém (Ribatejo) & Oil & Low & \\
\hline PT17 & Maçanilha Carrasquenha & Elvas (Alentejo) & Table & Medium & \\
\hline PT18 & Maçanilha de Elvas & Elvas (Alentejo) & Both use & Medium & \\
\hline PT19 & Maçanilha de Tavira & Tavira (Algarve) & Table & Medium & \\
\hline PT20 & Madural & Trás-os-Montes & Oil & Medium & \\
\hline PT21 & Mora & Elvas (Alentejo) & Oil & Medium & \\
\hline PT22 & Negrinha de Freixo & Trás-os-Montes & Table & Low & \\
\hline PT23 & Negrita & Trás-os-Montes & Table & Low & \\
\hline PT24 & Quinta do Portado & Santarém (Ribatejo) & Oil & Medium & \\
\hline PT25 & Redondal & Trás-os-Montes & Oil & Medium & \\
\hline PT26 & Redondil & Alto Alentejo & Both use & High & \\
\hline PT27 & Tentilheira & Elvas (Alentejo) & Oil & Low & \\
\hline PT28 & Verde Verdelho & Elvas (Alentejo) & Oil & Medium & \\
\hline РT29 & Verdeal de Serpa & Serpa (Alentejo) & Oil & Medium & \\
\hline PT30 & Verdeal de Trás-os-Montes & Trás-os-Montes & Oil & Medium & \\
\hline Med1 & Picual & & Oil & High & Spain \\
\hline Med2 & Leccino & & Oil & Medium & Italy \\
\hline Med3 & Merhavia & & Table & Low & Israel \\
\hline Med4 & Kalamata & & Table & Medium & Greece \\
\hline Med5 & Picholine & & Both use & Medium & France \\
\hline Med6 & Meski & & Table & Low & Tunisia \\
\hline Med7 & Izmir Sofralik & & Table & High & Turkey \\
\hline Med8 & Picholine Morocaine & & Both use & High & Morocco \\
\hline
\end{tabular}

${ }^{\mathrm{a}}$ Source: FAO (2005).

stage of amplification were optimised. A set of 20 oligonucleotide primers, from 107 tested Operon sets (OPA kit-1 to 20, OPC kit, OPE kit, OPO kit, OPX kit, OPQ15, OPQ17, OPS3, OPZ10, OPZ11, OPAA3 and OPAA11), was used to obtain specific molecular markers (Table 2).

The PCR reaction was composed of $1 \times \mathrm{PCR}$ buffer, $62.5 \mathrm{mM} \mathrm{MgCl} 2,10 \mathrm{mM}$ of dNTPs, $1.5 \mathrm{U}$ of Taq Polymerase (Fermentas), $50 \mathrm{ng}$ of primer, $70 \mathrm{ng}$ of template DNA and $\mathrm{ddH}_{2} \mathrm{O}$ to a final volume of $25 \mu \mathrm{L}$.

Amplifications were performed in a Biometra Tgradient thermocycler, with the following PCR cycle: $94^{\circ} \mathrm{C}, 3 \mathrm{~min} ; 94^{\circ} \mathrm{C}, 1 \mathrm{~min} ; 38^{\circ} \mathrm{C}, 1 \mathrm{~min}$; $72^{\circ} \mathrm{C}, 2 \mathrm{~min}$; repeat to step 2,44 times; $72^{\circ} \mathrm{C}$, $10 \mathrm{~min}$.

The amplification products were separated by gel electrophoresis on a $1.5 \%$ agarose gel, in $1 \times \mathrm{TBE}$ buffer during $2 \mathrm{~h}$ at $80 \mathrm{~V}$ and stained with ethidium bromide $(100 \mathrm{mg} / \mathrm{ml})$.

\section{ISSR amplification}

For the ISSR-PCR amplification we tested 100 primers from the set 100/9 (University of British Columbia). Seventeen primers were selected on base of the number of bands and their 
Table 2. Primers used for RAPD and ISSR analyses: total number, polymorphic, unique bands and \% of polymorphism obtained.

\begin{tabular}{|c|c|c|c|c|c|}
\hline Primer & Sequence $5^{\prime}-3^{\prime}$ & Total number of bands & Polymorphic bands & Unique bands & $\%$ Polymorphism \\
\hline PA1 & CAGGCCCTTC & 18 & 17 & 1 & 94 \\
\hline OPA13 & CAGCACCCAC & 19 & 15 & 0 & 79 \\
\hline OPC8 & CCCAAGGTCC & 22 & 18 & 2 & 81 \\
\hline OPC13 & GGTGCGGGAA & 14 & 13 & 5 & 93 \\
\hline OPE1 & GGTGACTGTG & 18 & 18 & 1 & 100 \\
\hline OPE2 & TGGACCGGTG & 18 & 16 & 0 & 89 \\
\hline OPE16 & AAGCCTCGTC & 10 & 8 & 1 & 80 \\
\hline OPO3 & CTGTTGCTAC & 6 & 5 & 0 & 83 \\
\hline OPO4 & AAGTCCGCTC & 19 & 18 & 0 & 95 \\
\hline OPO5 & CCCAGTCACT & 15 & 14 & 1 & 93 \\
\hline OPO6 & CCACGGGAAG & 17 & 14 & 0 & 82 \\
\hline OPO7 & CAGCACTGAC & 15 & 14 & 2 & 93 \\
\hline OPO10 & TCAGAGCGCC & 15 & 14 & 1 & 93 \\
\hline OPO12 & CAGTCGTGTG & 20 & 18 & 1 & 90 \\
\hline OPO13 & GTCAGAGTCC & 15 & 14 & 0 & 93 \\
\hline OPX3 & TGGCGCAGTG & 10 & 8 & 0 & 80 \\
\hline OPX14 & ACAGGTGCTG & 12 & 9 & 0 & 75 \\
\hline OPX15 & CAGACAAGCC & 11 & 8 & 0 & 73 \\
\hline OPX18 & GACTAGGTGG & 12 & 10 & 0 & 83 \\
\hline OPX19 & TGGCAAGGCA & 15 & 11 & 0 & 73 \\
\hline UBC 807 & $(\mathrm{AG})_{8} \mathrm{~T}$ & 11 & 11 & 0 & 100 \\
\hline UBC 809 & $(\mathrm{AG})_{8} \mathrm{G}$ & 13 & 11 & 0 & 85 \\
\hline UBC 810 & $(\mathrm{GA})_{8} \mathrm{~T}$ & 12 & 11 & 2 & 92 \\
\hline UBC 811 & $(\mathrm{GA})_{8} \mathrm{C}$ & 13 & 12 & 0 & 92 \\
\hline UBC 817 & $(\mathrm{CA})_{8} \mathrm{~A}$ & 13 & 13 & 0 & 100 \\
\hline UBC 823 & $(\mathrm{TC})_{8} \mathrm{C}$ & 10 & 9 & 0 & 90 \\
\hline UBC 825 & $(\mathrm{AC})_{8} \mathrm{~T}$ & 8 & 7 & 0 & 88 \\
\hline UBC 826 & $(\mathrm{AC})_{8} \mathrm{C}$ & 15 & 12 & 1 & 80 \\
\hline UBC 834 & $(\mathrm{AG})_{8} \mathrm{YT}$ & 9 & 6 & 1 & 67 \\
\hline UBC 841 & $(\mathrm{GA})_{8} \mathrm{YC}$ & 14 & 13 & 1 & 93 \\
\hline UBC 846 & $(\mathrm{CA})_{8} \mathrm{RT}$ & 9 & 7 & 0 & 78 \\
\hline UBC 849 & $(\mathrm{GT})_{8} \mathrm{YA}$ & 14 & 13 & 0 & 93 \\
\hline UBC 850 & $(\mathrm{GT})_{8} \mathrm{TYC}$ & 14 & 14 & 0 & 100 \\
\hline UBC 855 & $(\mathrm{AC})_{8} \mathrm{YT}$ & 12 & 9 & 0 & 75 \\
\hline UBC 856 & $(\mathrm{GGAGA})_{3}$ & 15 & 15 & 0 & 100 \\
\hline UBC 880 & $(\mathrm{GGAGA})_{3}$ & 7 & 6 & 0 & 88 \\
\hline UBC 889 & $\mathrm{DBD}(\mathrm{AC})_{7}$ & 15 & 11 & 0 & 73 \\
\hline
\end{tabular}

$\mathrm{Y}=(\mathrm{CT}) ; \mathrm{R}=(\mathrm{AG}) ; \mathrm{D}=(\mathrm{AGT}) ; \mathrm{B}=(\mathrm{CGT})$.

reproducibility (Table 2). Each amplification reaction consisted of $1 \mu \mathrm{L}$ of total genomic DNA $(20 \mathrm{ng} / \mu \mathrm{L}), 1 \mu \mathrm{L}$ of primer $(5 \mu \mathrm{M}), 10 \mu \mathrm{L}$ of TaqPCR master mix (Qiagen) and $8 \mu \mathrm{L}$ of ultra-pure distilled water (Qiagen).

The amplifications were performed in a Biometra Tgradient thermocycler under the following conditions: $94^{\circ} \mathrm{C}, 5 \mathrm{~min} ; 94^{\circ} \mathrm{C}, 30 \mathrm{~s} ; 52^{\circ} \mathrm{C}, 45 \mathrm{~s}$; $72^{\circ} \mathrm{C}, 2 \mathrm{~min}$; repeat to step 2,45 times; $72^{\circ} \mathrm{C}$, 5 min.

The amplification products were separated by gel electrophoresis on a $1.5 \%$ agarose gel, in $1 \times$ TBE buffer during $2 \mathrm{~h}$ at $80 \mathrm{~V}$ and stained with ethidium bromide $(100 \mathrm{mg} / \mathrm{ml})$.

\section{Statistical analysis}

The PCR fragments were scored for the presence (1) or absence (0) of equally sized bands and two matrices of the different RAPD and ISSR phenotypes were assembled and used in the statistical analysis. The fragments were only considered when reproducible bands were obtained, meaning that for each primer we repeated the reaction three times with the same result. Cluster analysis was performed to construct dendrograms, with the unweighted pair-group method by arithmetic averages (UPGMA) from the similarity data matrices using Jaccard's coefficient. The Numerical 
Taxonomy and Multivariate Analysis System program package for personal computer (NTSYSPC V.2.02; Rohlf 1998) was used for statistical analysis of the data.

\section{Results}

\section{Polymorphism RAPD analysis and phenetic relationships}

A total of 301 reproducible bands, ranging from $190 \mathrm{bp}$ (primer OPX19) to 3,010 bp (primer OPO10) were detected using the 20 primers previously screened (Table 2). The number of bands per primer varied from 6 (OPO3) to 22 (OPC8) with an average of 16 bands per primer. Two hundred and sixty two bands $(87 \%)$ out of the 301 reproducible bands were polymorphic showing an average of 13.1 polymorphic markers per primer, ranging from 5 (OPO3) to 18 (OPC8, OPE1, OPO4, OPO12). The primers that showed the highest polymorphism were OPE1 and OPO4 with $100 \%$ and $95 \%$, respectively (Table 2 ).

Fifteen out of the 262 markers were cultivar-specific (Table 3). Eleven absent bands, present in all cultivars except one, were observed (Table 3). A total of seventeen cultivars could be distinguished from the others using RAPD primers. Independently, the primers OPC13, OPA1, OPO7 and OPC8 were able to distinguish three cultivars.

Genetic distances were obtained with UPGMA algorithm using Jaccard's coefficient (Figure 1). The genetic similarities ranged from 0.54 ('Cordovil de Serpa' - 'Izmir') to 0.79 ('Golosinha' 'Picholine'). The cultivars were grouped into two major clusters and five independent branches. Two out of the five branches belonged to foreign cultivars ('Izmir' and 'Leccino') and the other three belonged to Portuguese cultivars ('Cordovil de Serpa', 'Madural' and 'Leucocarpa').

\section{Polymorphism ISSR analysis and phenetic relationships}

A total of 204 reproducible ISSR bands were observed, of which 180 were polymorphic, accounting for a high percentage $(88 \%)$ of the observed polymorphism (Table 2), which ranged from 280 to $3,000 \mathrm{bp}$. All primers produced polymorphic bands, with an average of 12 ISSR markers per primer being scored, where the largest number (15) were obtained with primers UBC826, UBC856 and UBC889, and the lowest number (7) were obtained with primer UBC880.

Five out of the 180 markers were cultivar-specific and nine absent bands, present in all cultivars except one, were also observed (Table 3). A total of eleven cultivars could be distinguished from the others using only ISSR markers. Primer UBC810 allowed the discrimination of four different cultivars. The remaining primers were only able to distinguish one of the cultivars studied.

The dendrogram of the ISSR markers of 38 olive cultivars is shown in Figure 2. The genetic similarities ranged from 0.55 ('Leucocarpa' - 'Madural') to 0.84 ('Cordovil Castelo Branco' - 'Redondil'). The cultivars were grouped into 3 clusters and 4 independent branches, curiously, belonging to Portuguese cultivars ('Galega', 'Negrinha de Freixo', 'Madural' and 'Leucocarpa'). The last two also formed independent branches when RAPD markers were analysed (Figure 1).

\section{Combined phenetic relationship}

In order to have an overview of the genetic similarities/distance between the olive cultivars under study, a combined UPGMA analysis was performed, using Jaccard's coefficient (Figure 3). The genetic similarities ranged from 0.54 ('Leucocarpa' - 'Cordovil de Serpa') to 0.79 ('Blanqueta' 'Kalamata'). Four major clusters and five independent branches were obtained. Four of these branches belonged to Portuguese cultivars ('Negrinha de Freixo', 'Madural', 'Cordovil de Serpa' and 'Leucocarpa') and only one fit in a foreign cultivar ('Izmir').

Cluster I contained 16 Portuguese and 3 foreign olive cultivars. In cluster II, 9 Portuguese and 1 foreign cultivar from Morocco were present. Cluster III included one foreign cultivar 'Kalamata' and the Portuguese cultivar 'Blanqueta'. In cluster IV two foreign cultivars were present (see Figure 3).

Several close relationships between cultivars were constant in all the analyses performed: 'Kalamata' and 'Blanqueta'; 'Cordovil de Castelo Branco' and 'Redondil'; 'Golosinha' and 'Picholine'; and 'Cornicabra' and 'Merhavia', whereas, 
Table 3. Combination of different molecular markers used to identify and discriminate the 30 Portuguese and 8 foreign olive cultivars, referring the primer and band of each marker, as well as the specific markers for some olive cultivars.

\begin{tabular}{|c|c|c|c|}
\hline Cultivars & Unique bands & Unique missing bands & Discriminating markers \\
\hline Azeiteira & - & UBC823-670 & OPC8-2005, UBC889-910 \\
\hline Blanqueta & - & UBC856-705 & OPE16-987 \\
\hline Borrenta & - & - & OPC8-2005 \\
\hline Carrasquenha & OPC13-1092 & - & OPX18-700, UBC826-1910 \\
\hline Cobrançosa & - & - & UBC 826-1910 \\
\hline Conserva de Elvas & - & - & OPO3-465 \\
\hline Cordovil de C. B & OPE16-480 & - & OPO3-465, OPO10-820 \\
\hline Cordovil de Elvas & - & OPA1-1050, UBC810-2100 & UBC889-490 \\
\hline Cordovil de Serpa & UBC810-470 & OPE16-610, OPA1-350 & - \\
\hline Cordovil de T.M. & OPC13-1282 & - & - \\
\hline Cornicabra & - & - & OPX18-700 \\
\hline Galega & - & OPO4-736, UBC846-1100 & OPO13-700, OPO12-1046 \\
\hline Galego de Évora & - & - & UBC $850-610$ \\
\hline Galego G. S & $\begin{array}{l}\text { UBC } 826-680 \\
\text { UBC841-510 }\end{array}$ & UBC810-630 & OPO7-111 \\
\hline Golosinha & - & - & OPO13-700, OPX18-700, UBC850-610 \\
\hline Leucocarpa & UBC810-1320 & $\begin{array}{l}\text { OPA13-532, OPC8-888, } \\
\text { OPO7-748, UBC810-1475 }\end{array}$ & $\begin{array}{l}\text { OPA1-769, OPA13-1787, } \\
\text { OPO10-820, UBC } 889-910 \\
\text { UBC } 810-1320, \text { OPC } 8-888\end{array}$ \\
\hline Maçanilha C. & - & - & OPO12-1046 \\
\hline Maçanilha de E. & - & - & OPO7-111, UBC889-910 \\
\hline Maçanilha de T. & OPO10-820 & - & OPO10-510, OPO13-700 \\
\hline Madural & OPO7-1116 & - & OPO7-111, UBC850-610, UBC889-910 \\
\hline Mora & - & - & OPA13-1787 \\
\hline Negrinha de Freixo & $\begin{array}{l}\text { OPC13-334; 1400; 1528, } \\
\text { UBC } 834-800\end{array}$ & OPC13-986 & OPE16-987, OPO12-496 \\
\hline Negrita & OPA1-2108, OPE1-976 & - & - \\
\hline Quinta do Portado & - & - & UBC $889-490$ \\
\hline Redondal & - & - & OPO12-496, OPO12-1046 \\
\hline Redondil & - & - & OPO3-465, OPO10-510, UBC889-910 \\
\hline Tentilheira & OPO7-1757 & OPO4-675 & UBC850-610 \\
\hline Verde Verdelho & OPC8-748 & - & OPO4-1311 \\
\hline Verdeal de Serpa & OPO12-617 & - & - \\
\hline Verdeal de T. M. & - & - & OPA1-2108 \\
\hline Picual & OPC8-566 & - & - \\
\hline Leccino & - & UBC880-490 & OPX18-700, OPO12-1046 \\
\hline Merhavia & - & - & UBC889-910, UBC889-490 \\
\hline Kalamata & - & - & OPE16-987 \\
\hline Picholine & - & UBC $825-810$ & UBC826-1910, UBC823-670 \\
\hline Meski & OPO5-306 & UBC889-887 & OPX18-700, UBC850-610, OPO12-1046 \\
\hline Izmir Sofralik & - & OPO6-2286, OPX18-550 & UBC $889-490$ \\
\hline Picholine Morocaine & - & - & OPA1-769, OPO4-1311 \\
\hline
\end{tabular}

the Portuguese cultivars 'Madural' and 'Leucocarpa' always presented independent branches in all three analyses. 'Negrinha de Freixo' was an independent branch in the ISSR and in combined analyses (Figures 2 and 3), but was integrated in cluster II of the RAPD analysis. Nevertheless, it was the first to derivate from that cluster. 'Cordovil de Serpa' had a similar performance as 'Negrinha de Freixo', because it was an independent branch in the RAPD and combined analyses
(Figures 1 and 3), although it was integrated in cluster I of the ISSR dendrogram (Figure 2).

Most of the foreign cultivars were not clustered independently from the Portuguese cultivars in general, once they were dispersed in all clusters obtained in the different analyses. Only the cultivar 'Izmir' was an independent branch in both RAPD and combined dendrograms (Figures 1 and 3 ), but in the ISSR analysis it belonged to cluster III (Figure 2). 


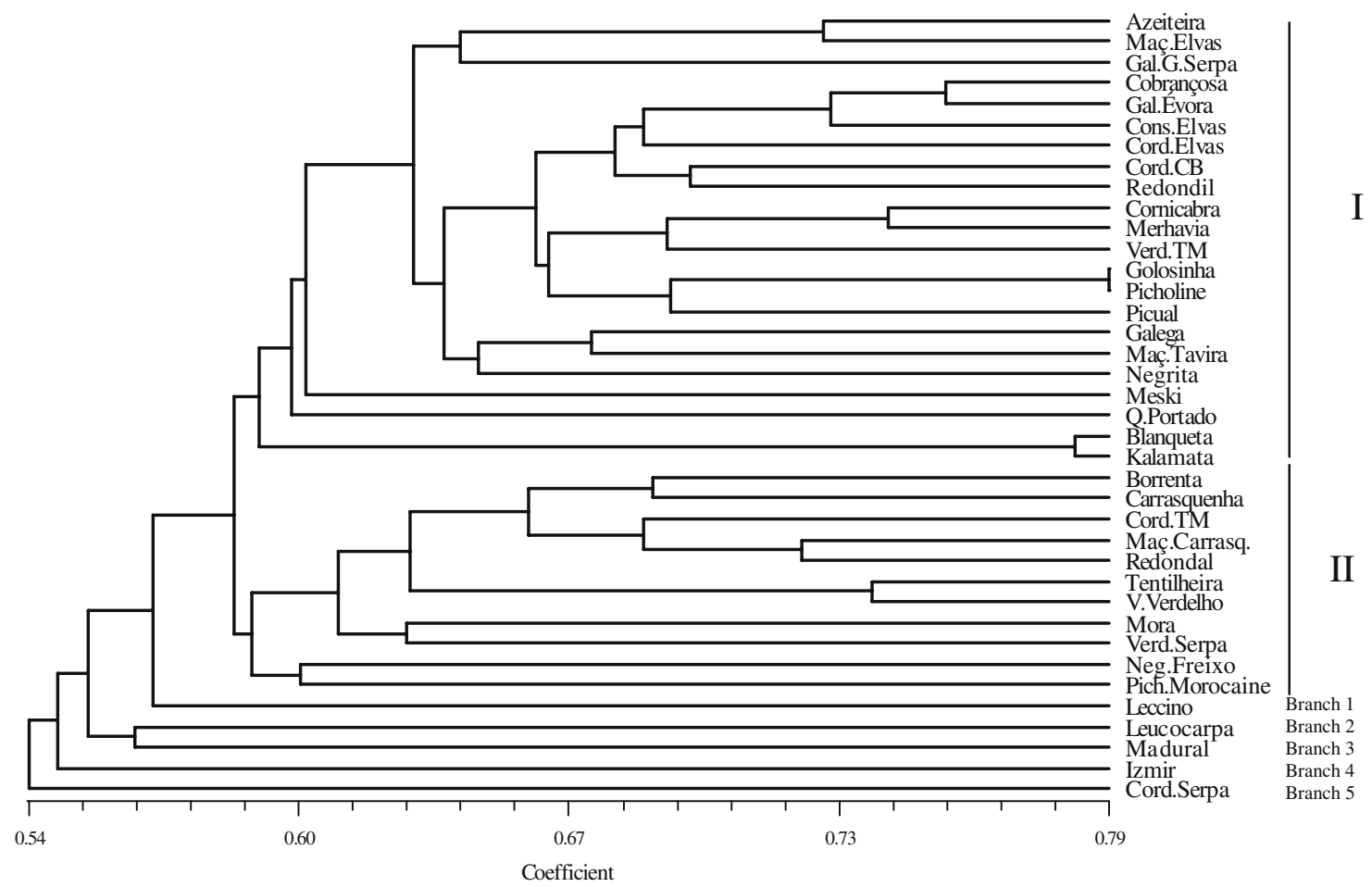

Figure 1. UPGMA dendrogram based on Jaccard's coefficient illustrating the genetic similarities and distance among olive cultivars obtained by RAPD data, generated by the UPGMA cluster analysis (NTSYS).

No relationship to geographic origin and enduse in Portuguese cultivars was found (figure not shown).

\section{Discussion}

In our work, the olive cultivars under study formed different groups when RAPD (Figure 1) and ISSR (Figure 2) primers were used independently. This can be explained by the fact that ISSR primers target specific genome regions, while a RAPD primer amplify arbitrary regions.

\section{Combined phenetic relationship}

RAPD and ISSR techniques revealed a high level of polymorphism. There were no significant differences between the genetic variability obtained in the group of Portuguese olive cultivars and in the foreign cultivars. In RAPDs the percentage of polymorphism observed was 50.8 and $47.75 \%$, for Portuguese and foreign cultivars, respectively.
Slightly higher values were registered for ISSR (57.4\% for Portuguese cultivars and $58.75 \%$ for foreign ones) what confirmed that the ISSR marker system is more polymorphic than RAPD in many plant species (Nagaoka and Ogihara 1997; Korbin et al. 2002; Galvan et al. 2003). These values were at the same level as the polymorphism reported within 12 clones of 3 Italian olive tree cultivars by AFLP (Sensi et al. 2003). The high polymorphism for RAPDs observed in comparison with other studies (Nagaoka and Ogihara 1997, Korbin et al. 2002, Galvan et al. 2003) may also be due to the high selection pressure of the primers, 20 most informative ones out of 107 primers initially used.

The high level of polymorphism observed in this study and in other reports of Portuguese (Gemas et al. 2004; Lopes et al. 2004) and foreign cultivars (Fabbri et al. 1995; Weisman et al. 1998; Barranco et al. 2000; Belaj et al. 2003a, b; Terzopoulos et al. 2005) indicated that olive is a highly polymorphic species. The high diversity found between olive cultivars is probably due to a diverse germplasm origin, that presumably results from crosses 


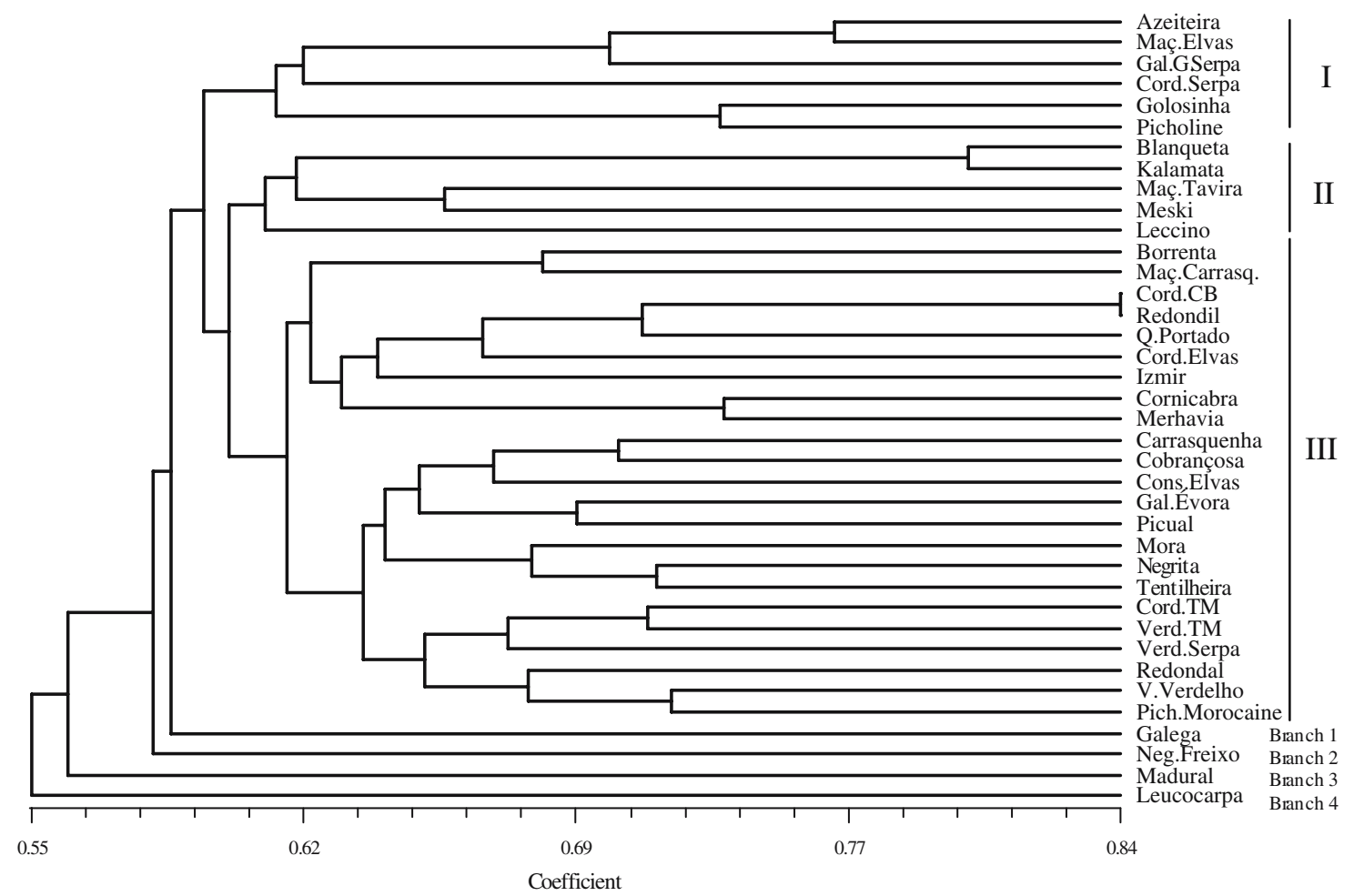

Figure 2. UPGMA dendrogram based on Jaccard's coefficient illustrating the genetic similarities and distance among olive cultivars obtained by ISSR data, generated by the UPGMA cluster analysis (NTSYS).

between wild and cultivated olives resulting in new cultivars in different parts of the Mediterranean, and low breeding pressures (Besnard et al. 2001a; Contento et al. 2002; Belaj et al. 2003c).

This may also explain why in the dendrograms no distinction was observed between foreign and Portuguese cultivars. The same was observed between French and foreign cultivars, and in sample of Mediterranean cultivars (Besnard et al. 2001a). No relationship to geographic origin between Portuguese and foreign cultivars was found in our work. Khadari et al. (2003) using French and foreign olive cultivars and Besnard et al. (2001a) analysing 102 genotypes from several Mediterranean countries have reported similar results. However, in some cases a clustering of cultivars of the same region was observed (Besnard et al. 2001a; Bandelj et al. 2004).

In terms of olive end-use (oil, table and both use) we could not find any clear clustering, oppositely to studies of Besnard et al. (2001a) and Gemas et al. (2004). This could be explained by the fact that the number of cultivars and primers used in the previous studies were different. Gemas et al. (2004) analysed only 11 of the 30 Portuguese cultivars used in our study. They did not use ISSR in their study, which may not be covering the entire range of variability available in the genoma.

In the dendrogram obtained from our data several cultivars were consistently very far apart from the rest of the cultivars studied. Surprisingly, four of these cultivars were Portuguese ('Negrinha de Freixo', 'Madural', 'Leucocarpa' and 'Cordovil de Serpa'). 'Leucocarpa' was already suspected to be an outsider, due to its morphological characteristics (very small white fruit), commonly known as an albino wild Oleaster.

The distinct phenetic position of 'Madural' was previously reported with RAPD markers (Gemas et al. 2004) and SSR markers (Lopes et al. 2004). Belaj et al. (2002) also reported a distant phenetic position of 'Cordovil de Serpa', in relation to the other cultivars. 'Negrinha' was reported to be linked with 'Cobrançosa', 'Azeiteira' and 'Negrita' when SSR markers are used (Lopes et al. 2004), 


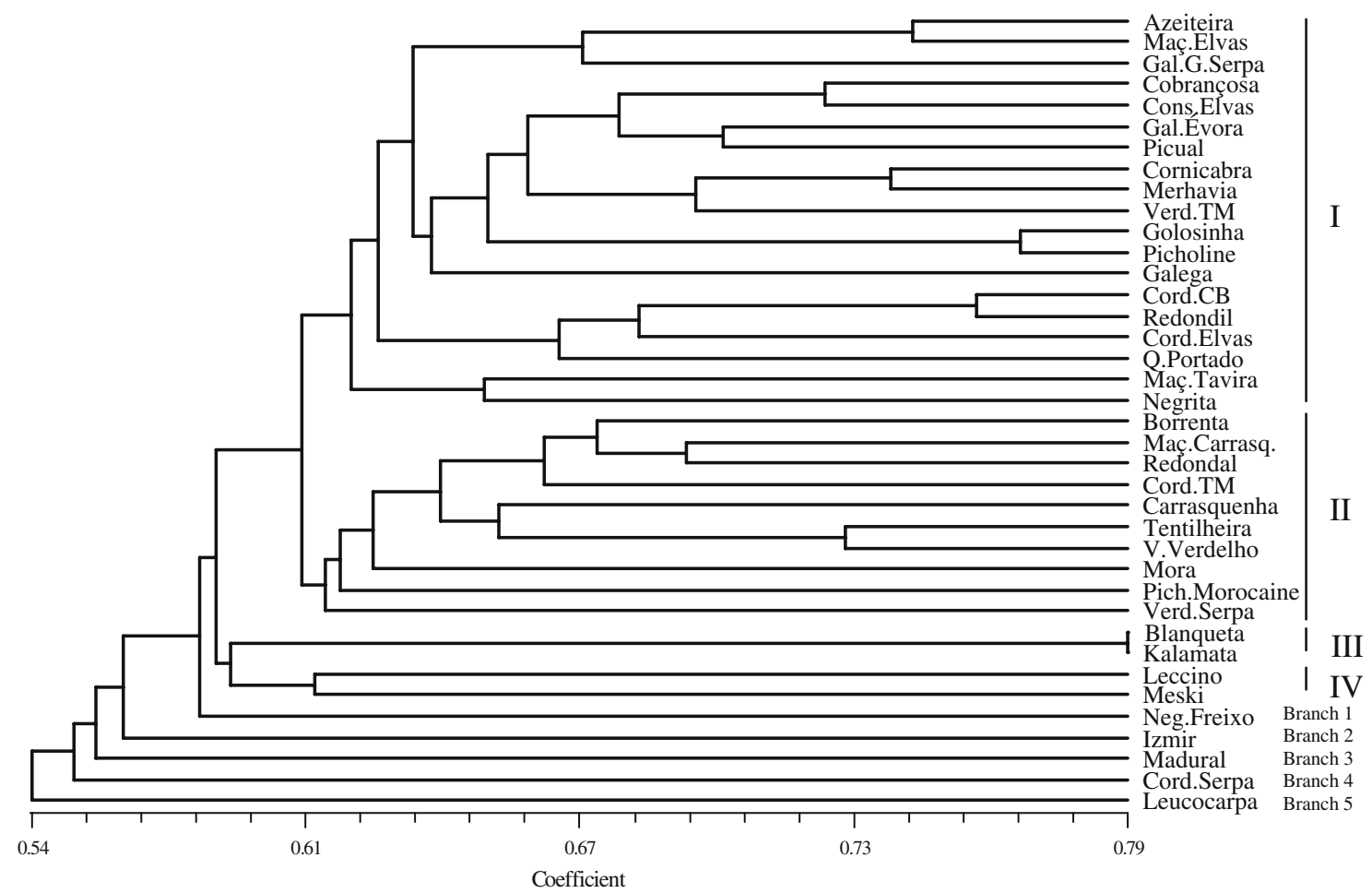

Figure 3. UPGMA dendrogram based on Jaccard's coefficient illustrating the genetic similarities and distance among olive cultivars obtained by RAPD and ISSR data, generated by the UPGMA cluster analysis (NTSYS).

and with 'Azeiteira' when RAPD markers are used (Gemas et al. 2004). However, in our study 'Negrinha de Freixo is an independent branch. This supports that 'Negrinha' used in previous studies is not the same cultivar as 'Negrinha de Freixo'.

Gemas et al. (2004) reported that 'Galega' and 'Blanqueta' are also two independent branches. We could confirm this fact for 'Galega' when the ISSR data were considered, but not in the RAPD and in combined analysis (Figures 2 and 3). The differences found between these studies might be due to the different number of primers analysed and to different marker systems used. In our analysis, 'Blanqueta' was associated with 'Kalamata', which is quit interesting because the phenotype analysis of these two cultivars revealed that both have very long leaves. Although the similarities in leaf length and genetic distance, 'Kalamata' and 'Blanqueta' could not be considered as synonymies once they differ in other important phenotypical characteristics, like fruit shape, and end-use.
In our study, the cultivars 'Golosinha' and 'Picholine' revealed to be related to each other. However, they are distinctive cultivars not only because their origin, end-use and oil content are different (see Table 1), but also due to different morphological specificities such as different fruit size and leaf shape and colour.

\section{Cultivars synonymous and homonymous}

The ability to distinguish among cultivars and to clarify synonymous and homonymous is of major importance for solving problems like olive germplasm management and nursery mislabelling.

Similar Portuguese cultivar designations may induce the hypothesis that those cultivars were genetically related. On the basis of genetic similarity showed in Figure 3, the analyses of all the three 'Galega' cultivars ('Galega', 'Galego de Évora', and 'Galego Grado de Serpa') confirmed that they were closely related. However, all 'Cordovil' cultivars ('Cordovil de Castelo Branco', 
'Cordovil de Elvas', 'Cordovil de Serpa' and 'Cordovil de Trás-os-Montes') appeared to be genetically different. The same was observed in the case of the two 'Verdeal' cultivars ('Verdeal de Serpa' and 'Verdeal de Trás-os-Montes'). These results could be explained probably by their geographical distances. We could relate two of the three 'Maçanilha' cultivars ('Maçanilha de Elvas' and 'Maçanilha de Tavira') but the third one, 'Maçanilha Carrasquenha', was closer to the other homonymous, 'Carrasquenha'. All the results presented here are consistent with those reported by Lopes et al. (2004) using SSR markers. These studies may help olive germplasm databases in organising the files relating to each olive cultivar.

In terms of synonymous, although in FAO's database for olive germplasm (www.fao.org) 'Madural' and 'Cornicabra' are considered as the same cultivar, this was not confirmed by our results (Figure 3), or by Lopes et al. (2004). As a matter of fact they have distinct morphological characters ('Madural' has an oval average fruit and short and wide leaves with light green colour, while 'Cornicabra' shows a long oval fruit with longer leaves and medium green colour). Instead, we found that 'Cornicabra' was closely linked with 'Merhavia', an Israeli cultivar, although they differ from leaf size.

\section{Differential discrimination of the olive cultivars by $R A P D$ and ISSR molecular markers}

The molecular polymorphism observed among the olive genotypes was appropriate to differentiate cultivars. All the Portuguese olive tree cultivars, plus the eight from foreign countries, spread in the Mediterranean basin, revealed RAPD and ISSR molecular markers that allowed identification of each one of the studied cultivars. As far as we know, it is the first time that RAPD and ISSR markers were able to identify the complete Portuguese standard cultivars collection of Olea europaea L. Other markers (AFLP, mtDNA RFLP, SSR, tandem repeated DNA sequences) were also used in several European olive cultivars studied for establishing its genetic variability, genetic relationships and genotyping (Pasqualone et al. 2001; Contento et al. 2002; Belaj et al. 2003b; Sensi et al. 2003; Khadari et al. 2003; Bandelj et al. 2004).
In our work, five ISSR and 15 RAPD primers allowed the screening of 20 molecular markers specific to different cultivars, which can be converted into SCAR markers for individual cultivar identification analysis (Hernández et al. 2001; Bautista et al. 2002).

\section{Conclusions}

The diversified origin of olive germplasm in the Mediterranean basin could be established. The genetic variability among the thirty Portuguese cultivars was at the same level as the one observed in the group of the foreign cultivars studied. The genetic affinities between Portuguese cultivars could be found in some cases but not in others.

Our data also showed the relevance of molecular studies for management and olive genetic resources conservation. The results of this study indicated that RAPD and ISSR techniques constitute a useful tool to find new specific molecular markers that allowed us to identify individually all the 38 olive cultivars studied.

\section{Acknowledgements}

This work was supported by "OLIV-TRACK" program from EU QLK1-CT-2002-02386. We thank to Dr. Perry Gustafson for suggestions and reviewing.

\section{References}

Bandelj D., Jakse J. and Javornik B. 2002. Characterisation of olive (Olea europaea L.) cultivars by RAPD markers. Acta Hort. 586: 133-135.

Bandelj D., Jakse J. and Javornik B. 2004. Assessment of genetic variability of olive varieties by microsatellite and AFLP markers. Euphytica 136: 93-102.

Barranco D., Cimato A., Fiorino P., Rallo L., Touzani A., Castañeda C., Serafín F. and Trujillo I. 2000. World Catalogue of Olive Varieties. Consejo Oleícola Internacional Madrid, España.

Bautista P., Crespillo R., Cánovas F. and Claros M. 2002. Identification of olive tree cultivars with SCAR markers. Euphytica 129: 33-41.

Belaj A., Caballero J.M., Barranco D., Rallo L. and Trujillo I. 2003a. Genetic characterization and identification of new accessions from Syria in an olive germplasm bank by means of RAPD markers. Euphytica 134: 261-268. 
Belaj A., Satovic Z., Ciprian G., Baldoni L., Testolin R., Rallo L. and Trujillo I. 2003b. Comparative study of the discriminating capacity of RAPD, AFLP and SSR markers and their effectiveness in establishing genetic relationship in olive. Theor. Appl. Genet. 107: 736-744.

Belaj A., Satovic Z., Ismaeli H., Panajoti D., Rallo L. and Trujillo I. 2003c. RAPD genetic diversity of Albanian olive germplasm and its relationships with other Mediterranean countries. Euphytica 130: 387-395.

Belaj A., Satovic Z., Rallo L. and Trujillo I. 2002. Genetic diversity and relationships in olive (Olea europaea L.) germplasm collections as determined by randomly amplified polymorphic DNA. Theor. Appl. Genet. (online DOI 10.1007/s00122-002-0981-6).

Besnard G., Baradat P. and Berville A. 2001a. Genetic relationship in the olive (Olea europaea L.) reflect multilocal selection of cultivars. Theor. Appl. Genet. 102: 251-258.

Besnard G., Baradat P., Chevalier D., Tagmonount A. and Berville A. 2001b. Genetic differentiation in the olive complex (Olea europaea L.) revealed by RAPDs and RFLPs in the rRNA genes. Genet. Resour. Crop Evol. 48: 165-182.

Contento A., Ceccarelli M. and Gelati M.T. 2002. Diversity of Olea genotypes and the origin of cultivated olives. Theor. Appl. Genet. 104: 1229-1238.

Cresti M., Linskens H.F., Mulchay D.L., Bush S., Di Stilo V., Xu M.Y., Vignani R. and Cimato A. 1996. Preliminary communication about the identification of DNA in leaves and in olive oil of Olea europaea. Adv. Hort. Sci. 10: 105-107.

Doyle J.J. and Doyle J.L. 1987. A rapid DNA isolation procedure for small quantities of fresh leaf tissue. Focus 12: 1315.

Fabbri A., Hormaza J.I. and Polito V.S. 1995. Random amplified polymorphic DNA analysis of olive (Olea europaea L.) cultivars. J. Am. Soc. Hortic. Sci. 120: 538-542.

Fang D.Q. and Roese M.L. 1997. Identification of closely related citrus cultivars with inter-simple sequence repeat markers. Theor. Appl. Genet. 95: 408-417.

Ford R., Pang E.C.K. and Taylor P.W.J. 1997. Diversity analysis and species identification in Lens using PCR generated markers. Euphytica 96: 257-255.

Fritsch P. and Rieseberg L.H. 1996. The use of random amplified polymorphic DNA (RAPD) in conservation genetics. In: Smith T.B. and Wayne R.K. (eds.), in Conservation. Oxford University Press, London, pp. 54-73.

Galvan M.Z., Bornet B., Balatti P.A. and Branchard M. 2003. Inter simple sequence repeat (ISSR) markers as a tool for the assessment of both genetic diversity and gene pool origin in common bean (Phaseolus vulgaris L.). Euphytica 132: 297301.

Gemas V.J.V., Almadanim M.C., Tenreiro R., Martins A. and Fevereiro P. 2004. Genetic diversity in the Olive tree (Olea europaea L. subsp. europaea) cultivated in Portugal revealed by RAPD and ISSR markers. Genet. Resour. Crop Evol. 51: 501-511.

Hernández P., Rosa R., Rallo L. and Dorado G. 2001. Development of SCAR markers in olive (Olea europaea) by direct sequencing of RAPD products: applications in olive germplasm evaluation and mapping. Theor. Appl. Genet. 103: 788-791.

Hess J., Kadereit J.W. and Vargas P. 2000. The colonization history of Olea europaea L. in Macaronesia based on internal transcribed spacer 1 (ITS-1) sequences, randomly amplified polymorphic DNAs (RAPD), and intersimple sequence repeats (ISSR). Mol. Ecol. 9: 857-867.

FAO. 2005. http://www.fao.org/(accessed in July 2005).

Kantety R.V., Zeng X.P., Bennetzen J.L. and Zehr B.E. 1995. Assessment of genetic diversity in Dent and Popcorn (Zea mays L.) inbred lines using inter-simple sequence repeat (ISSR) amplification. Mol. Breed. 1: 365-373.

Khadari B., Breton C., Moutier N., Roger P.J., Besnard G., Berville A. and Dosba F. 2003. The use of molecular markers for germplasm management in a French olive collection. Theor. Appl. Genet. 106: 521-529.

Kojima T., Nagaoka T., Noda K. and Ogihara Y. 1998. Genetic linkage map of ISSR and RAPD markers in Einkorn wheat in relation to that of RFLP markers. Theor. Appl. Genet. 96: 37-45.

Korbin M., Kuras A. and Urawicz E. 2002. Fruit plant germplasm characterisation using molecular markers generated in RAPD and ISSR PCR. Cell Mol. Biol. Lett. 7(2B): 785-794.

Lopes S.M., Mendonça D., Sefc K.M., Sabino Gil F. and Câmara Machado A. 2004. Genetic evidence of intra-cultivar variability within Iberian olive cultivars. Hort Sci. 39(7): 1562-1565.

Loureiro M.D., Marminez M.C., Boursiquot J.M. and This P. 1998. Molecular markers analysis of Vitis vinifera Albarino and some similar Grapevine cultivars. J. Am. Soc. Hort. Sci. 123(5): 842-848.

Mekuria G., Collins G. and Sedgley M. 2002. Genetic diversity within an isolated olive (Olea europaea L.) population in relation to feral spread. Sci. Hort. 94: 91-105.

Mekuria G.T., Collins G.G. and Sedgley M. 1999. Genetic variability between different accessions of some common commercial olive cultivars. J. Hort. Sci. Biotech. 74: 309-314.

Nagaoka T. and Ogihara Y. 1997. Applicability of inter-simple sequence repeat polymorphisms in wheat for use as DNA markers in comparison to RFLP and RAPD markers. Theor. Appl. Genet. 94: 597-602.

Pasqualone A., Caponio F. and Blanco A. 2001. Inter-simple sequence repeat DNA markers for identification of drupes from different Olea europaea L. cultivars. Eur. Food Res. Technol. 213: 240-243.

Qian W., Ge S. and Hong D.Y. 2001. Genetic variation within and among populations of a wild rice Oryza granulate from China detected by RAPD and ISSR markers. Theor. Appl. Genet. 102: 440-449.

Rakoczy-Trojanowska M. and Bolibok H. 2004. Characteristics and a comparison of three classes of microssatellite-based markers and their application in plants. Cell. Mol. Biol. Lett. 9: 221-238.

Rallo P., Dorado G. and Martin A. 2000. Development of simple sequence repeats (SSRs) in olive tree (Olea europaea L.). Theor. Appl. Genet. 101: 984-989.

Rohlf M 1998. NTSYS-PC. Numerical Taxonomy and Multivariate Analysis System, Version 2.02i. Department of Ecology and Evolution, State University of New York, Setauket, NY.

Roselli G., Petruccelli L., Polsinelli L. and Cavalieri D. 2002. Variability in five Tuscan olive cultivars (Olea europaea L.). J. Genet. Breed. 56: 51-60.

Schnell R.J., Ronning C.M. and Knight R.J. 1995. Identification of cultivars and validation of genetic relationships in 
Mangifera indica L. using RAPD markers. Theor. Appl. Genet. 90: 269-274.

Sensi E., Vignani R., Scali M., Masi E. and Cresti M. 2003. DNA fingerprinting and genetic relatedness among cultivated varieties of Olea europaea L. estimated by AFLP analysis. Sci. Hort. 97: 378-388.

Terzopoulos P.J., Kolano B., Bebeli P.J., Kaltsikes P.J. and Metzidakis 2005. Identification of Olea europaea L. cultivars using inter-simple sequence repeat markers. Sci. Hort. 105: $45-51$.

Wiesman Z., Avidan N., Lavee S. and Quebedeaux B. 1998. Molecular characterization of common olive varieties in Israel and the West bank using randomly amplified polymorphic DNA (RAPD) markers. J. Am. Soc. Hortic. Sci. 123: $837-841$.
Williams J.K., Kubelik A.R., Livak K.J., Rafalski J.A. and Tingey S.V. 1990. DNA polymorphisms amplified by arbitrary primers are useful as genetic markers. Nucleic Acids Res. 18: 6531-6535.

Yang W.P., Oliveira A.C., Godwin I., Schertz K. and Bennetzen J.L. 1996. Comparison of DNA marker technologies in characterizing plant genome diversity: variability in Chinese sorghums. Crop Sci. 36: 1669-1676.

Zietkiewicz E., Rafalski A. and Labuda D. 1994. Genome fingerprinting by simple sequence repeat (SSR)-anchored polymerase chain reaction amplification. Genomics 20: 176-183.

Zohary D. and Spielgel R.P. 1975. Beginnings of fruit growing in Old World. Science 187: 319-327. 